\title{
Analysis of the Current Wastewater Recycling Standards
}

\author{
Zhang Xiaoxin ${ }^{1}$, Huang Jin $^{1 *}$, Lin Ling ${ }^{1}$, Wang Xiuteng ${ }^{1}$, Liu Jing ${ }^{1}$, Fang Fei ${ }^{1}$ and Zhang Sinan ${ }^{1}$ \\ ${ }^{1}$ China National Institute of Standardization, 100191 Beijing, China
}

\begin{abstract}
This study summarized the current development of wastewater recycling standards in China by analyzing published policies, existing national, industrial and local standards, as well as related activities in typical provinces. Meanwhile, further prospects for standardization in the area were also suggested in order to promote this industry.
\end{abstract}

\section{Introduction}

The theme of World Water Day 2021 is Valuing Water. According to the statistics of World Bank, the world suffers an economic loss of up to USD250 billion each year due to insufficient water supply or sanitation services, and 675,000 people die prematurely due to poor water quality, or poor environmental health or personal hygiene, with some countries suffering GDP losses as high as 7\%. The water crisis led to change of people's traditional ideas about water management, and constant exploration and appreciation of value of different forms of water with innovative technologies and management models. Among the endeavors, wastewater recycling is most significant.

In January 2021, ten ministries and commissions including the National Development and Reform Commission jointly issued Guiding Opinions on Promoting Wastewater Recycling, pointing out that the wastewater, which meets the quality standards after harmless treatment, will replace conventional water used for industrial, municipal, domestic, ecological, agricultural and groundwater recharging purposes as a recycled water, and extraction of other resources and energy from wastewater is of great significance for optimizing the structure of water supply, diversifying water resources, alleviating the contradiction between water supply and demand, reducing water pollution, and ensuring water ecological safety. The guideline called for expedited improvement of policies and standards, and incorporation of recycled water into the urban water supply system. It proposed development and revision of local standards on water pollutants discharge, and differentiated requirements and measures for pollutants discharge and control. It also urged development of technical specifications and requirements on use of recycled water as ecological replenishment water, timely revision of standards on classification of quality of wastewater used for other purposes, as well as development and revision of standards on relevant equipment, engineering and operations.

\section{Current situation of standardization}

\subsection{Existing standards on wastewater}

Existing national, industrial and local standards on wastewater recycling are shown in Table.1.

Table1. Existing Standards on Wastewater Recycling

\begin{tabular}{|c|c|c|c|}
\hline $\begin{array}{l}\text { Seria } \\
\text { I No. }\end{array}$ & $\begin{array}{c}\text { Standard } \\
\text { No. }\end{array}$ & Standard name & Type \\
\hline 1 & $\begin{array}{c}\mathrm{GB} / \mathrm{T} \\
18919-2002\end{array}$ & $\begin{array}{l}\text { Urban } \\
\text { Wastewater } \\
\text { Recycling- } \\
\text { Classification }\end{array}$ & $\begin{array}{l}\text { National } \\
\text { standard }\end{array}$ \\
\hline 2 & $\begin{array}{c}\mathrm{GB} / \mathrm{T} \\
18920-2002\end{array}$ & $\begin{array}{l}\text { Urban } \\
\text { Wastewater } \\
\text { Recycling- } \\
\text { Quality of Urban } \\
\text { Miscellaneous } \\
\text { Water }\end{array}$ & $\begin{array}{l}\text { National } \\
\text { standard }\end{array}$ \\
\hline 3 & $\begin{array}{c}\mathrm{GB} / \mathrm{T} \\
18921-2002\end{array}$ & $\begin{array}{l}\text { Urban } \\
\text { Wastewater } \\
\text { Recycling- } \\
\text { Quality of Water } \\
\text { for Scenic } \\
\text { Environment Use }\end{array}$ & $\begin{array}{l}\text { National } \\
\text { standard }\end{array}$ \\
\hline 4 & $\begin{array}{c}\mathrm{GB} / \mathrm{T} \\
19772-2005\end{array}$ & $\begin{array}{l}\text { Urban } \\
\text { Wastewater } \\
\text { Recycling- } \\
\text { Quality of Water } \\
\text { for Groundwater } \\
\text { Recharging }\end{array}$ & $\begin{array}{l}\text { National } \\
\text { standard }\end{array}$ \\
\hline 5 & $\begin{array}{c}\mathrm{GB} / \mathrm{T} \\
19923-2005\end{array}$ & $\begin{array}{l}\text { Urban } \\
\text { Wastewater } \\
\text { Recycling- } \\
\text { Quality of Waster } \\
\text { for Industrial Use }\end{array}$ & $\begin{array}{l}\text { National } \\
\text { standard }\end{array}$ \\
\hline 6 & $\begin{array}{c}\text { GB 20922- } \\
2007\end{array}$ & $\begin{array}{l}\text { Urban } \\
\text { Wastewater } \\
\text { Recycling - } \\
\text { Quality of Water } \\
\text { for Farmland } \\
\text { Irrigation }\end{array}$ & $\begin{array}{l}\text { National } \\
\text { standard }\end{array}$ \\
\hline
\end{tabular}

\footnotetext{
* Corresponding author: huangjin@cnis.ac.cn
} 


\begin{tabular}{|c|c|c|c|}
\hline 7 & $\begin{array}{c}\text { GB 20922- } \\
2007\end{array}$ & $\begin{array}{l}\text { Urban } \\
\text { Wastewater } \\
\text { Recycling - } \\
\text { Quality of Water } \\
\text { for Farmland } \\
\text { Irrigation }\end{array}$ & $\begin{array}{l}\text { National } \\
\text { standard }\end{array}$ \\
\hline 8 & $\begin{array}{c}\mathrm{GB} / \mathrm{T} \\
25499-2010\end{array}$ & $\begin{array}{l}\text { Urban } \\
\text { Wastewater } \\
\text { Recycling - } \\
\text { Quality of Water } \\
\text { for Landscape } \\
\text { Irrigation }\end{array}$ & $\begin{array}{l}\text { National } \\
\text { standard }\end{array}$ \\
\hline 9 & $\begin{array}{c}\mathrm{GB} / \mathrm{T} \\
22597-2014\end{array}$ & $\begin{array}{l}\text { Determination of } \\
\text { Chemical Oxygen } \\
\text { Demand in } \\
\text { Recycled Water - } \\
\text { Potassium } \\
\text { Dichromate } \\
\text { Method }\end{array}$ & $\begin{array}{l}\text { National } \\
\text { standard }\end{array}$ \\
\hline 10 & $\begin{array}{c}\mathrm{GB} / \mathrm{T} \\
37905-2019\end{array}$ & $\begin{array}{l}\text { Quality of } \\
\text { Recycled Water - } \\
\text { Determination of } \\
\text { Chromium } \\
\text { Polarography and } \\
\text { Voltammetry } \\
\end{array}$ & $\begin{array}{l}\text { National } \\
\text { standard }\end{array}$ \\
\hline 11 & $\begin{array}{c}\mathrm{GB} / \mathrm{T} \\
37906-2019\end{array}$ & $\begin{array}{l}\text { Quality of } \\
\text { Recycled Water - } \\
\text { Determination of } \\
\text { Mercury - } \\
\text { Mercury } \\
\text { Vapourmeter } \\
\text { Method }\end{array}$ & $\begin{array}{l}\text { National } \\
\text { standard }\end{array}$ \\
\hline 12 & $\begin{array}{c}\mathrm{GB} / \mathrm{T} \\
37907-2019\end{array}$ & $\begin{array}{l}\text { Quality of } \\
\text { Recycled Water - } \\
\text { Determination of } \\
\text { Sulfide and } \\
\text { Cyanide - Ion } \\
\text { Chromatography } \\
\end{array}$ & $\begin{array}{l}\text { National } \\
\text { standard }\end{array}$ \\
\hline 13 & $\begin{array}{c}\mathrm{GB} / \mathrm{T} \\
27681-2011\end{array}$ & $\begin{array}{l}\text { Specification on } \\
\text { Zero Discharge } \\
\text { and Recycling of } \\
\text { Cooling Water } \\
\text { During Melting } \\
\text { and Casting of } \\
\text { Copper and } \\
\text { Copper Alloy }\end{array}$ & $\begin{array}{l}\text { National } \\
\text { standard }\end{array}$ \\
\hline 14 & $\begin{array}{c}\mathrm{GB} / \mathrm{T} \\
29773-2013\end{array}$ & $\begin{array}{l}\text { Specification on } \\
\text { Recycling of } \\
\text { Wastewater from } \\
\text { Copper } \\
\text { Concentrators } \\
\end{array}$ & $\begin{array}{l}\text { National } \\
\text { standard }\end{array}$ \\
\hline 15 & $\begin{array}{c}\mathrm{GB} / \mathrm{T} \\
30888-2014\end{array}$ & $\begin{array}{l}\text { Technical } \\
\text { Specifications on } \\
\text { Treatment and } \\
\text { Recycling of } \\
\text { Textile } \\
\text { Wastewater by } \\
\text { Membrane } \\
\text { Method } \\
\end{array}$ & $\begin{array}{l}\text { National } \\
\text { standard }\end{array}$ \\
\hline 16 & $\begin{array}{c}\mathrm{GB} / \mathrm{T} \\
31189-2014\end{array}$ & $\begin{array}{lr}\text { Technical } & \\
\text { Specification on } \\
\text { Recovery }\end{array}$ & $\begin{array}{l}\text { National } \\
\text { standard }\end{array}$ \\
\hline
\end{tabular}

\begin{tabular}{|c|c|c|c|}
\hline 17 & $\begin{array}{c}\mathrm{GB} / \mathrm{T} \\
38224.1- \\
2019\end{array}$ & $\begin{array}{lr}\text { Evaluation } & \text { of } \\
\text { Heavy Metal } \\
\text { Wastewater } \\
\text { Treatment and } \\
\text { Recycling } \\
\text { Technology Part } \\
\text { 1: Procedure and } \\
\text { Approach }\end{array}$ & $\begin{array}{l}\text { National } \\
\text { standard }\end{array}$ \\
\hline 18 & $\begin{array}{c}\mathrm{GB} / \mathrm{T} \\
38224.2- \\
2019\end{array}$ & $\begin{array}{l}\text { Evaluation of } \\
\text { Heavy Metal } \\
\text { Wastewater } \\
\text { Treatment and } \\
\text { Recycling } \\
\text { Technology Part } \\
\text { 2: Index System }\end{array}$ & $\begin{array}{l}\text { National } \\
\text { standard }\end{array}$ \\
\hline 19 & $\begin{array}{c}\text { FZ/T } 01107- \\
2011\end{array}$ & $\begin{array}{lr}\text { Quality } & \text { of } \\
\text { Recycled } & \text { Water } \\
\text { Used for } & \text { Textile } \\
\text { Dyeing } & \text { and } \\
\text { Finishing Industry }\end{array}$ & $\begin{array}{l}\text { Industry } \\
\text { Standard }\end{array}$ \\
\hline 20 & $\begin{array}{c}\text { TB/T 3007- } \\
2000\end{array}$ & $\begin{array}{l}\text { Quality Standard } \\
\text { for Recycled } \\
\text { Water Used for } \\
\text { Railway Industry }\end{array}$ & $\begin{array}{l}\text { Industry } \\
\text { Standard }\end{array}$ \\
\hline 21 & $\begin{array}{c}\text { CJJ 252- } \\
2016\end{array}$ & $\begin{array}{l}\text { Technical } \\
\text { Specifications on } \\
\text { the Operation, } \\
\text { Maintenance and } \\
\text { Safety of Urban } \\
\text { Water Recycling } \\
\text { Plants }\end{array}$ & $\begin{array}{l}\text { Industry } \\
\text { Standard }\end{array}$ \\
\hline 22 & $\begin{array}{l}\text { DL/T 5483- } \\
2013\end{array}$ & $\begin{array}{l}\text { Code for Design } \\
\text { of Advanced } \\
\text { Treatment of } \\
\text { Recycled Water } \\
\text { from Thermal } \\
\text { Power Plants }\end{array}$ & $\begin{array}{l}\text { Industry } \\
\text { Standard }\end{array}$ \\
\hline 23 & $\begin{array}{c}\mathrm{HG} / \mathrm{T} \\
3923-2007\end{array}$ & $\begin{array}{l}\text { Quality } \text { Standard } \\
\text { for Recycled } \\
\text { Water Used for } \\
\text { Circulation } \\
\text { Cooling }\end{array}$ & $\begin{array}{l}\text { Industry } \\
\text { Standard }\end{array}$ \\
\hline 24 & $\begin{array}{c}\mathrm{HG} / \mathrm{T} \\
4325-2012\end{array}$ & $\begin{array}{l}\text { Determination of } \\
\text { Calcium and } \\
\text { Magnesium } \\
\text { Contents in } \\
\text { Recycled Water - } \\
\text { Atomic } \\
\text { Absorption } \\
\text { Spectrometry } \\
\end{array}$ & $\begin{array}{l}\text { Industry } \\
\text { Standard }\end{array}$ \\
\hline 25 & $\begin{array}{c}\mathrm{HG} / \mathrm{T} \\
4326-2012\end{array}$ & $\begin{array}{l}\text { Determination of } \\
\text { Nickel, Copper, } \\
\text { Zinc, Cadmium } \\
\text { and Lead Contents } \\
\text { in Recycled Water } \\
\text { - Atomic } \\
\text { Absorption } \\
\text { Spectrometry }\end{array}$ & $\begin{array}{l}\text { Industry } \\
\text { Standard }\end{array}$ \\
\hline 26 & $\begin{array}{c}\mathrm{HG} / \mathrm{T} \\
4327-2012\end{array}$ & $\begin{array}{l}\text { Determination of } \\
\text { Total Iron Content } \\
\text { in Recycled } \\
\text { Water- } \\
\text { Spectrophotometr } \\
\text { ic Method }\end{array}$ & $\begin{array}{l}\text { Industry } \\
\text { Standard }\end{array}$ \\
\hline 27 & $\begin{array}{l}\text { SL 368- } \\
2006\end{array}$ & $\begin{array}{ll}\text { Quality } & \text { Standard } \\
\text { for } & \text { Recycled } \\
\text { Water } & \\
\end{array}$ & $\begin{array}{l}\text { Industry } \\
\text { Standard }\end{array}$ \\
\hline
\end{tabular}




\begin{tabular}{|c|c|c|c|}
\hline 28 & $\begin{array}{c}\text { SL 760- } \\
2018\end{array}$ & $\begin{array}{lr}\text { Guideline for } \\
\text { Compilation } & \text { of } \\
\text { Specifications } & \text { on } \\
\text { Urban } & \\
\text { Wastewater } & \\
\text { Recycling } & \end{array}$ & $\begin{array}{l}\text { Industry } \\
\text { Standard }\end{array}$ \\
\hline 29 & $\begin{array}{l}\text { JT/T } 645.1- \\
2016\end{array}$ & $\begin{array}{l}\text { Wastewater } \\
\text { Recycling in } \\
\text { Highway Service } \\
\text { Areas Part 1: } \\
\text { Water Quality }\end{array}$ & $\begin{array}{l}\text { Industry } \\
\text { Standard }\end{array}$ \\
\hline 30 & $\begin{array}{c}\text { JT/T 645.2- } \\
\quad 2016\end{array}$ & $\begin{array}{l}\text { Wastewater } \\
\text { Recycling in } \\
\text { Highway Service } \\
\text { Areas Part 2: } \\
\text { Technical } \\
\text { Requirements for } \\
\text { Treatment } \\
\text { Systems }\end{array}$ & $\begin{array}{l}\text { Industry } \\
\text { Standard }\end{array}$ \\
\hline 31 & $\begin{array}{c}\text { JT/T 645.3- } \\
\quad 2016\end{array}$ & $\begin{array}{l}\text { Wastewater } \\
\text { Recycling in } \\
\text { Highway Service } \\
\text { Areas Part 3: } \\
\text { Operation and } \\
\text { Management } \\
\text { Requirements for } \\
\text { Treatment } \\
\text { Systems } \\
\end{array}$ & $\begin{array}{l}\text { Industry } \\
\text { Standard }\end{array}$ \\
\hline 32 & $\begin{array}{c}\text { HG/T } \\
5309-2018\end{array}$ & $\begin{array}{l}\text { Technical } \\
\text { Specifications on } \\
\text { Treatment and } \\
\text { Recovery of } \\
\text { Electroplating } \\
\text { Copper- } \\
\text { containing } \\
\text { Wastewater } \\
\end{array}$ & $\begin{array}{l}\text { Industry } \\
\text { Standard }\end{array}$ \\
\hline 33 & $\begin{array}{c}\text { HG/T } \\
5361-2018\end{array}$ & $\begin{array}{l}\text { Technical } \\
\text { Specifications on } \\
\text { Treatment and } \\
\text { Recovery of } \\
\text { Coking } \\
\text { Desulfurization } \\
\text { and Decyanation } \\
\text { Wastewater }\end{array}$ & $\begin{array}{l}\text { Industry } \\
\text { Standard }\end{array}$ \\
\hline 34 & $\begin{array}{c}\text { HJ 2019- } \\
2012\end{array}$ & $\begin{array}{l}\text { Technical } \\
\text { Specifications on } \\
\text { Treatment and } \\
\text { Recycling of } \\
\text { Wastewater from } \\
\text { Iron and Steel } \\
\text { Industry }\end{array}$ & $\begin{array}{l}\text { Industry } \\
\text { Standard }\end{array}$ \\
\hline 35 & $\begin{array}{l}\text { YS/T 1169- } \\
\quad 2017\end{array}$ & $\begin{array}{l}\text { Technical } \\
\text { Specifications on } \\
\text { Treatment and } \\
\text { Recycling of } \\
\text { Wastewater from } \\
\text { Secondary Lead } \\
\text { Production }\end{array}$ & $\begin{array}{l}\text { Industry } \\
\text { Standard }\end{array}$ \\
\hline 36 & $\begin{array}{c}\mathrm{YS} / \mathrm{T} 1404- \\
2020\end{array}$ & $\begin{array}{l}\text { Technical } \\
\text { Specifications on } \\
\text { Recycling of Lead } \\
\text { Smelting } \\
\text { Wastewater }\end{array}$ & $\begin{array}{l}\text { Industry } \\
\text { Standard }\end{array}$ \\
\hline 37 & $\begin{array}{c}\text { YS/T 1405- } \\
2020\end{array}$ & $\begin{array}{lr}\text { Specifications on } \\
\text { Treatment and } \\
\text { Recycling } \\
\text { Lead-Zinc }\end{array}$ & $\begin{array}{l}\text { Industry } \\
\text { Standard }\end{array}$ \\
\hline
\end{tabular}

\begin{tabular}{|c|c|c|c|}
\hline & & $\begin{array}{l}\text { Beneficiation } \\
\text { Wastewater }\end{array}$ & \\
\hline 38 & $\begin{array}{l}\text { YS/T 740- } \\
2010\end{array}$ & $\begin{array}{l}\text { Determination of } \\
\text { Caustic Alkalinity } \\
\text { in Wastewater } \\
\text { from Alumina } \\
\text { Industry }\end{array}$ & $\begin{array}{l}\text { Industry } \\
\text { Standard }\end{array}$ \\
\hline 39 & $\begin{array}{c}\mathrm{T} / \mathrm{CSES} \\
01-2019\end{array}$ & $\begin{array}{lr}\text { Guideline } & \text { for } \\
\text { Evaluation } & \text { of } \\
\text { Benefits } & \text { of } \\
\text { Recycled Water }\end{array}$ & $\begin{array}{l}\text { Group } \\
\text { Standard }\end{array}$ \\
\hline 40 & $\begin{array}{c}\text { T/GIEHA } \\
007-2018\end{array}$ & $\begin{array}{l}\text { Qualification } \\
\text { Levels of Service } \\
\text { Agencies } \\
\text { Engaged in } \\
\text { Industrial and } \\
\text { Commercial } \\
\text { Circulating Water } \\
\text { Treatment }\end{array}$ & $\begin{array}{l}\text { Group } \\
\text { Standard }\end{array}$ \\
\hline 41 & $\begin{array}{c}\text { T/JX 003- } \\
2018\end{array}$ & $\begin{array}{l}\text { Specifications on } \\
\text { Engineering } \\
\text { Design } \\
\text { Wastewater of } \\
\text { Treatment and } \\
\text { Recycling of } \\
\text { Reclaimed Water } \\
\text { from Water Jet } \\
\text { Looms } \\
\end{array}$ & $\begin{array}{l}\text { Group } \\
\text { Standard }\end{array}$ \\
\hline 42 & $\begin{array}{c}\text { T/JX 002- } \\
2018\end{array}$ & $\begin{array}{l}\text { Specifications on } \\
\text { Construction and } \\
\text { Operation of } \\
\text { Reclaimed Water } \\
\text { Treatment Station } \\
\text { in Water Jet Loom } \\
\text { Industry }\end{array}$ & $\begin{array}{l}\text { Group } \\
\text { Standard }\end{array}$ \\
\hline 43 & $\begin{array}{c}\mathrm{T} / \mathrm{JX} 001- \\
2018\end{array}$ & $\begin{array}{l}\text { Quality } \\
\text { Requirements for } \\
\text { Reclaimed Water } \\
\text { in Water Jet Loom } \\
\text { Industry }\end{array}$ & $\begin{array}{l}\text { Group } \\
\text { Standard }\end{array}$ \\
\hline
\end{tabular}

\subsection{Current situation of standardization in selective provinces of China}

\subsubsection{Hebei Province}

The government of Hebei Province has released three local standards - Standards on Water Pollutants Discharged to Daqing River Basin, Standards on Water Pollutants Discharged to Ziya River Basin, and Standards on Water Pollutants Discharged to Heilonggang and Yundong Basins. In 2020, the Standards on Discharge by Sewage Treatment Plants in Hebei Province, which have stricter requirements than national standards, was officially implemented, with the treatment costs of up to 2 yuan per ton. These discharge standards are however not in harmony with the requirements for surface water quality across the province (assessed based on the cross section of water functional zones). The large difference in water quality is a hindrance to wastewater recycling. More standards on the treatment and recycling of wastewater from livestock and poultry breeding, and on the technology, equipment, and safety evaluation of recycled water for agricultural irrigation need to be developed. At the same time, it is necessary to develop an institutional 
framework guiding the market access of water-saving appliances. Continuous efforts are needed to build national and provincial green parks and green plants, and to guide and lead industrial enterprises in energy and water conservation, clean production, pollution prevention and control, and comprehensive utilization of resources.

\subsubsection{Yunnan Province}

The government of Yunnan Province has issued regulations on the protection of key lakes, and set water quotas and indexes for building sponge cities. As a result, the water quality of all sewage treatment plants in Dianchi Lake Basin conforms to the requirements for Class III-IV water bodies in GB 3838-2002 - Environmental Quality Standards for Surface Water, except for the total nitrogen content. Sewage treatment plants in other regions are currently in the process of upgrading the water quality from level B to level A. In the Water Quota in Yunnan Province, the government made clear the standards on water consumption intensity in production and life by specifying 1,135 water quotas for 143 industry sectors, including industrial production, farming and tourism. The nonconformity between the discharge standards and the requirements for surface water quality across the province, assessed based on the cross section of water functional zones, still exists. The large difference in water quality is a hindrance to wastewater recycling. It is necessary to develop standards on assessment of safety risk of recycled water for river replenishment (to Dianchi Lake), impact of recycled water for agricultural irrigation, and impact of long-term irrigation on shallow groundwater. Lijiang City, as a tourist city, needs more standards on treatment of wastewater from the catering industry and on building of a sponge city. Future efforts should be focused on the development of standards on equipment, products, technology, process, monitoring and testing in relation to disposal of river sediment (Dianchi), and centralized and decentralized wastewater treatment, to facilitate building of a sponge city.

\subsubsection{Zhejiang Province}

All sewage treatment plants in Zhejiang Province had completed upgrading by the year end of 2017, and starting from January 1, 2018, all urban sewage treatment plants in the province have been complying with level-A effluent standards. The Discharge Standards of Major Water Pollutants for Urban Sewage Treatment Plants issued by Zhejiang government (Zhejiang Standards, Surface Water Class 4) has been followed since January 1, 2019. In 2016, the local standard, Agricultural Water Quota of Zhejiang Province (DB33/T769-2016) was promulgated, specifying quotas for a total of 73 products in 13 industries. Meanwhile, 77 sets of water quotas have been revised for the textile and paper industries over the past two years under a joint dynamic quota revision mechanism. There is the same problem that the discharge standards are not in harmony with the requirements for surface water quality, assessed based on the cross section of water functional zones. Some sewage plants further purify the effluent by connecting the tail water to the ecological wetland, but no relevant standards on the technical processes and water quality are available. With the water recycling in industrial parks and wastewater collection in villages and towns in full swing, it is necessary to develop standards on water recycling performance, water quality, wastewater treatment appraisal and supervision by a third party.

\subsubsection{Gansu Province}

The Water Resources Department of Gansu Province issued the Implementation Measures of Gansu Province to Control the Use of Water Resources (G. Sh. Z.Y. F. [2019] No. 41). The Regulations of Gansu Province on Water Conservation, which was reported to the provincial People's Congress and the provincial government in 2017 is still under legislative survey today. It is urgent to harmonize the relevant indicators in the recycled water utilization standards and the natural water quality standards to reduce pollution caused by drainage of sewage treatment plants to natural water bodies and the environment. Due to the lower standards and lower quality indexes for ecological replenishment water, the discharged water and recycled water are still pollutants to natural water bodies (among the five classes of inferior water). Therefore, to enhance the wastewater discharge standards and water quality indexes is vital to protecting the ecological environment of water bodies.

\section{Prospects for standardization of wastewater recycling}

The wastewater recycling in China is still in its infancy, meaning that it has not been fully developed and the utilization level of recycled water is low, and thus is unable to meet the need of building a Beautiful China. In order to promote the development of the industry, and address such issues as water shortage, pollution of water environment and damage to water ecology, future efforts shall be focused on the following aspects.

1. Establishing a standard system for wastewater recycling and improving top-level design. A stand system that is well-balanced, perfectly structured, coordinated, open and inclusive, and where the government plays a guiding role and the market players play a dominant role, shall be established, to guide the efforts in establishing standards on technical process, equipment, products, management and services in wastewater treatment and recycling in urban and rural areas.

2. Accelerate development of key standards on wastewater recycling. The wastewater discharge standards should be harmonized with the recycled water quality requirements by taking into account the current standards and improvements needed for wastewater recycling in the regions. Technical standards on key equipment, materials, and water quality monitoring and testing methods in relation to wastewater cycling should be developed; standards on municipal or domestic water safety risk assessment should also be put in place to make recycled water more acceptable to the public; in terms of recycled water from breeding, standards on safety assessment of 
farmland irrigation technology, health and safety, and impact of long-term irrigation on groundwater should be developed.

3. Conducting wastewater recycling pilot demonstration projects. Key enterprises, parks and regions may be selected to pilot wastewater recycling according to a standardization management system developed based on national, industrial, local and group standards, and their model of success may be replicated in other regions to regulate and promote the development of the wastewater recycling industry in China.

4. Contributing to development of international standards on wastewater recycling. Contribution to development of intentional standards may be made by proposing marketable and competitive wastewater recycling technology or management methods or by leading or participating in the process; more Chinese technical standards should be translated into foreign languages, and advanced foreign standards should be adaptively applied, to form a standard development model of absorption, digestion and innovation. Coordination with the International Organization for Standardization, the international certification authorities and international peers should be strengthened, to enable cross-regional coordination and mutual recognition of standards with other countries.

\section{References}

1. National Development and Reform Commission. Guiding Opinions on Promoting Wastewater Recycling (2021)

2. S Gen-xing, D Qian, Y Fan, G Jinxin, Z Bolang, L Jianping. J. Shanxi Uni. Sci. Tech, 3(2014).

3. Z Xiaoxin, H Jin, L Lin, L Shuming. W Yueping, Z Xinheng. 2019 IOP Conf. Ser.: Earth Environ. Sci. 267 (2019).

4. Z Chunyuan, Z Yong. J. China Water Resources, 1(2020)

5. M Tao, L Jiufu, P Anbang, et al. J. Advances in Water Science. 31(6)(2020) 